\title{
Trade Openness, Domestic and Foreign Investments, and the Environment
}

\author{
Eskandar Elmarzougui ${ }^{1,2 *}$, Bruno Larue ${ }^{2}$, Lota D. Tamini2 \\ ${ }^{1}$ Department of Economics, Laval University, Québec, Canada \\ ${ }^{2}$ Department of Agricultural Economics and Consumer Sciences, Laval University, Québec, Canada \\ Email: "eskandar.elmarzougui.1@ulaval.ca, bruno.larue@eac.ulaval.ca, lota.tamini@eac.ulaval.ca
}

Received 31 March 2016; accepted 15 May 2016; published 18 May 2016

Copyright (C) 2016 by authors and Scientific Research Publishing Inc.

This work is licensed under the Creative Commons Attribution International License (CC BY).

http://creativecommons.org/licenses/by/4.0/

(c) (†) Open Access

\begin{abstract}
This paper studies the impact of growth, and trade and investment openness on the environment at the regional level. We find support for the environmental Kuznet Curve hypothesis for $\mathrm{CO}_{2}$ emissions in Africa, Asia and OECD countries. We show that Foreign Direct Investment (FDI) has detrimental effects on $\mathrm{CO}_{2}$ emissions in Africa, the Middle East and North Africa, the former United Socialist Soviet Republic and Eastern Europe, and South America, but not in Asia where it seems to have beneficial effects. FDI raises $\mathrm{SO}_{2}$ emissions in South America, although it does lower them in Africa. Local investment is contributing significantly to both $\mathrm{CO}_{2}$ and $\mathrm{SO}_{2}$ emission increases in most regions while trade openness reduces (increases) $\mathrm{CO}_{2}$ in $\mathrm{OECD}$ countries (South America).
\end{abstract}

\section{Keywords}

$\mathrm{CO}_{2}$ and $\mathrm{SO}_{2}$ Emissions, Domestic Investment, Foreign Direct Investment, Trade Openness, ARDL

\section{Introduction}

In this paper, we seek to contribute to the debate on the effects of economic growth and trade and investment liberalization on the environment. Much effort has been invested in multilateral and bilateral trade negotiations since the mid-1980s. These efforts have not been productive at the multilateral level, as a conclusion to the Doha Round seems unattainable. In contrast, the number of regional trade agreements has grown very rapidly and the empirical evidence is that more trade has been created than diverted (e.g., Magee, 2008 [1]). However, environmental issues are typically excluded from trade negotiations. The debate regarding the linkages between international trade, Foreign Direct Investment (FDI), and the environment remains unresolved (Cole and Elliott,

*Corresponding author. 
2005 [2]; and Levinson and Taylor, 2008 [3]) ${ }^{1}$. Grossman and Krueger (1993 [4], 1995 [5]) found that economic growth, starting at low income levels bring about environmental degradation until a threshold income level is reached beyond which economic growth ends up bringing environmental improvements. This inverted U-shaped relationship is commonly referred to as the Environmental Kuznets Curve (EKC), but the robustness of this result has been questioned ${ }^{2}$. Not surprisingly, the resolution of the debate has taken different directions: choice of pollutants, choice of country groupings, the inclusion or not of variables like trade and foreign direct investment and the treatment of numerous econometric issues like endogeneity, dynamic adjustments ${ }^{3}$, and the use of parametric versus semiparametric estimators. Frankel and Rose (2005) [6] made an important contribution by accounting for the endogeneity of trade in their estimation on cross sectional data. They found that trade openness reduces two measures of air pollution (sulphur dioxide and nitrogen dioxide) and does not seem to have detrimental effects on the other environmental indicators.

Many studies have investigated the relationship between growth, openness and the environment at a more disaggregated level (with respect to the countries' level of development or their regional appertaining). Hoffman et al. (2005) [7] have shown that the causal relation from Foreign Direct Investment (FDI) to pollution $\left(\mathrm{CO}_{2}\right.$ and $\mathrm{SO}_{2}$ emissions) is conditioned by the host country's level of development. Harbaugh, Levinshon, and Wilson (2002) [8] found that air pollution estimates are sensitive to functional forms, the presence of additional independent variables and the choice of geographic locations. Lee, Chiu and Sun (2010) [9] disaggregated their sample of 97 countries into four regions when trying to ascertain the plausibility of an Environmental Kuznet Curve (EKC) for water pollution. They did not find support for the EKC in the full sample, but did find an EKC for Europe and America when the sample was split. Bernard et al. (2015) [10] disaggregated their samples into seven regions and found evidence of an EKC in OECD countries and not elsewhere. Managi, Hibiki and Tsurumi (2009) [11] have investigated the impact of trade openness on the environment in OECD and non-OECD countries and found trade-induced environmental benefits in the former and detrimental and beneficial effects in the latter.

In this paper, we investigate the impact of trade and investment openness on emissions of carbon dioxide and sulphur dioxide $\left(\mathrm{CO}_{2}\right.$ and $\left.\mathrm{SO}_{2}\right)$ for a long and wide panel covering well over 100 countries and 48 years. Our main innovation is the decomposition of investment into domestic and foreign components to gauge the extent by which their respective effect on the environment differ. The only study that differentiates foreign and domestic investments to our knowledge is conducted by Yong, Brosig and Chen (2012) [12] on Chinese provinces over the period 1992-2008. For many countries, income, investment and pollutant emission series display persistence over time. Thus, the specification of the model should allow for rich dynamic adjustments and accumulation processes. We also address the endogeneity of income, trade and domestic and foreign investments. Economic activity brings about changes in environmental quality through the physical scale of production. It is also generally believed that public demand for environmental quality increases with per capita income. In the presence of democratic institutions, a stronger demand for environmental quality should bring about stricter environmental regulations which in turn should impact on real income. For instance, output growth cannot be sustained indefinitely if environmental degradation exhibits irreversibility (Arrow et al. 1995) [13]. As such, one would expect national income and environmental quality to be determined simultaneously (Tahvonen and Kuuluvainen 1993 [14]; Van Ewiijk and Van Wijnbergen 1995 [15]; Stern et al. 1996 [16]) and this is why Coondoo and Dinda (2002) [17] argue that causality between income and environmental quality is not unidirectional.

According to the race to the bottom hypothesis, countries that are more open to international trade and FDI may adopt looser environmental standards as a mean to boost their competitiveness. But, openness itself can also ease the transfer of technological and managerial innovations from countries with high standards to countries with low standards, thus inducing an international "ratcheting" of environmental standards (Vogel 1995 [18]; Braithwaite and Drahos 2000 [19]) leading to improvements in environmental quality, which is known as the pollution halo hypothesis. The Porter hypothesis (Porter and Van der Linde 1995 [20]) points out that the tigh-

\footnotetext{
${ }^{1}$ Some authors like Tobey (1990) and Van Beers and Van der Bergh (1997) investigated the causal link from domestic environmental regulation to international trade as opposed to the effect of trade on the environment.

${ }^{2}$ Perman and Stern (2003) use panel-data cointegration tests about a long run concave relationship between sulfur emissions and per capita income. Their results show that the series are not always cointegrated and that when they are, the sign of the coefficients of the long run relation are not always consistent with the EKC hypothesis.

${ }^{3}$ Stern (2010) suggests the between estimator to tackle the cross-sectional dependence and time effect problems documented by Wagner (2008) and Vollebergh, Melenberg and Dijkgraaf (2010). He also argues that time varying technological changes will not be captured by time dummies and will lead to a contemporaneous correlation between regressors and country effects and/or residual errors.
} 
tening of environmental standards can stimulate technological innovations enough to improve the competitiveness of high-standard countries and increase their volume of trade and investment with the rest of the world. Clearly, trade and investment should be treated as endogenous variables.

Disaggregating our panel into regions necessarily reduces the number of countries in each regression and this is why we rely on panel data techniques that are reliable in this context. Our full sample includes 157 countries for $\mathrm{CO}_{2}$ and 140 for $\mathrm{SO}_{2}$ and it spans the period 1960-2007. We disaggregate it into several regional and income groupings: Africa, Asia, Central America and the Caribbean, the former United Socialist Soviet Republic and Eastern European countries (former USSR \& Eastern Europe), the Middle East and North Africa (MENA), South America and the OECD countries ${ }^{4}$.

The rest of this paper is structured as follows. Our econometric framework is presented in Section 2. Our estimation strategy, data sources and equation reparameterization are discussed in Section 3. Section 4 focuses on the interpretation of the results and Section 5 concludes.

\section{Econometric Framework}

In the spirit of Frankel and Rose (2005) [6], we assume that the long run relationship among $\mathrm{CO}_{2}$ (and $\mathrm{SO}_{2}$ ) emissions, economic growth, local investment, foreign direct investment and trade openness can be estimated by the following empirical specification ${ }^{5}$ :

$$
E M_{\text {kit }}=\alpha_{0 i}+\alpha_{1}(y / p o p)_{i t}+\alpha_{2}(y / p o p)_{i t}^{2}+\alpha_{3}(I / p o p)_{i t}+\alpha_{4}(F D I / p o p)_{i t}+\alpha_{5} T_{i t}+\varepsilon_{i t}
$$

The dependent variable (EM) is the per capita emissions of $\mathrm{CO}_{2}$ and $\mathrm{SO}_{2}$. Our specification posits that the level of emission $E M_{k i t}$, of pollutant $k$ in country $i$ at time $t$, is conditioned by per capita real gross domestic product ( $y /$ pop), per capita domestic investment (I/pop), per capita foreign direct investment (FDI/pop) and trade openness intensity $(T)$. The introduction of $(y / p o p)$ is intended to capture the scale effect as income plays an important role in the determination of the environmental outcomes. Its squared value $(y / p o p)^{2}$ is considered to allow for non linearities which may arise from non homotheticities in production or consumption to support the EKC (Cole and Elliott 2003 [21]). The EKC hypothesis would be verified if the coefficient on the per capita GDP is positive and that on the squared per capita GDP is negative.

$T_{i t}$ in Equation (1) is defined as the ratio of the sum of exports and imports to GDP (trade openness intensity). (FDI/pop) $)_{i t}$ represents per capita net productive foreign direct investment for country $i$ at time $t . \varepsilon_{i t}$ is an idiosyncratic error term, $\varepsilon_{i t}$ represents the omitted impact of other causes. The intercept $\alpha_{0 i}$ includes a country fixed effect whose purpose is to control for any country specific effect that may affect pollutant emissions differently across countries. Differences in environmental regulations for example or in abatement technologies are captured by country fixed effects. The fixed effects capture unobservable heterogeneity or specific characteristics that vary across countries, but are constant over time. Sources of comparative advantage, natural resources, natural harbors, proximity to markets, and investment-friendly business climates are all examples of country fixed effects. Additional assumptions on the residual errors and regressors are discussed in the following section.

\section{Estimation Strategy and Data}

\subsection{Estimation Strategy}

Endogeneity in Equation (1) is an obvious problem that can be tackled by the two stage least squares estimator (2SLS) proposed by Baltagi and Li (1992) [22]. Similarly, persistence is another crucial problem. Assuming that $\varepsilon_{i t}$ is a first order autoregressive process ${ }^{6}$, we can write the autoregressive dynamic representation of our environmental equation as:

\footnotetext{
${ }^{4}$ Our disaggregation is similar to that of Stern (2005), Ma and Stern (2006) and Bernard et al. (2015).

${ }^{5}$ Given the long period spanned by our sample, we did not find a polity variable available for all of the countries and all of the years of our sample. Because they use a cross-section, Frankel and Rose (2005) did not encounter this problem. We attempted to use participation in environmental agreements as a proxy, but it was not statistically significant. However, by disaggregating the sample into relatively homogenous regions, the quality of the institutions ends up being captured by the intercepts. Countries making up an aggregate tend to have similar scores on the corruption perception index (CPI) developed by the international transparency agency. The presence of trend was also tested and found to be not significant.

${ }^{6}$ This hypothesis was assumed by Pesaran, Shin and Smith (1999), Matinez-Zaarzoso and Bengochea-Morancho (2004) and Bernard et al. (2015) and is also plausible in our case. Residual are regressed over their lagged values and found to be not correlated (Durbin and Watson (1950) and Bhargava, Franzini, and Narendranathan (1982)).
} 


$$
\begin{aligned}
E M_{k i t}= & \alpha_{0 i}+\delta_{0} E M_{\text {kit-1 }}+\alpha_{1}(y / p o p)_{i t}+\alpha_{2}(y / p o p)_{i t}^{2}+\alpha_{3}(I / p o p)_{i t} \\
& +\alpha_{4}(F D I / p o p)_{i t}+\alpha_{5} T_{i t}+\alpha_{11}(y / p o p)_{i t-1}+\alpha_{21}(y / p o p)_{i t-1}^{2} \\
& +\alpha_{31}(I / p o p)_{i t-1}+\alpha_{41}(F D I / p o p)_{i t-1}+\alpha_{51} T_{i t-1}+u_{i t}
\end{aligned}
$$

where the residual error term $u_{i t}$ is temporally uncorrelated.

A spurious regression problem may arise because of the time series properties of the data. One solution is to induce stationarity in $I(1)$ series by applying a first-difference transformation. An alternative is to exploit the existence of one or more long-run equilibrium relationships among variables, provided such relationships actually exist. Recent advances in panel cointegration analysis have facilitated the estimation of models using non stationary panels, including cases with long and wide panels $N$ (i.e., $T$ and/or $N$ are large). The asymptotics of large $N$, large $T$ or fixed $N$ and large $T$ are different from cases with large $N$ and small $T$ or fixed $N$ and small $T .^{7}$ In this paper, we will rely on an estimator introduced by Pesaran, Shin and Smith (1999) [23]. This estimator is referred to as the Auto-Regressive Distributed Lag (ARDL) estimator, and it is based on the general-to-specific modeling technique. The ARDL has several advantages over other cointegration estimators and this is why it has become popular in empirical research. Matinez-Zaarzoso and Bengochea-Morancho (2004) [24] have used it in the estimation of an environmental Kuznet Curve in a panel of 22 OECD countries over the period 1975-1998. One of the main advantages of this technique is that it can be applied irrespective of whether the variable are $I(0), I(1)$ or fractionally cointegrated ${ }^{8}$ (Pesaran, Shin and Smith 1999 [23]; Jalil and Mahmud 2009 [25]). The other advantage is that the error correction representation (ECR) can be derived from ARDL through a simple linear transformation of the original autoregressive dynamic equation, as will be shown below. The ECR allows for the characterization of short-run adjustments around the long-run equilibrium without losing information about the long run. Furthermore, the endogeneity of explanatory variables is not problematic with the ARDL estimator because variables entering the error correction relation are endogenous, unless restricted to be exogenous in some way. ${ }^{9}$ The ARDL approach is a lot simpler to implement than the instrumental variable approach featured in Frankel and Rose (2005) [6] to deal with endogenous regressors. Finally, the autoregressive component of the ARDL squarely tackles serial correlation problems (Pesaran, Shin and Smith 1999 [23]).

The error correction reparameterization of Equation (2) takes the following form ${ }^{10}$ :

$$
\begin{aligned}
\Delta E M_{\text {kit }}= & \phi_{i}\left(E M_{\text {kit }-1}-\theta_{0 i}-\theta_{1}(y / \text { pop })_{i t}-\theta_{2}(y / \text { pop })_{i t}^{2}-\theta_{3}(I / p o p)_{i t}-\theta_{4}(F D I / p o p)_{i t}-\theta_{5} T_{i t}\right) \\
& -\alpha_{11} \Delta(I / p o p)_{i t}-\alpha_{21} \Delta(y / p o p)_{i t}^{2}-\alpha_{31} \Delta(I / p o p)_{i t}-\alpha_{41} \Delta(F D I / p o p)_{i t}-\alpha_{51} \Delta T_{i t}+\varepsilon_{i t}
\end{aligned}
$$

where: $\phi_{i}=\delta_{0}-1, \quad \theta_{0 i}=\frac{\alpha_{0 i}}{1-\delta_{0}}, \theta_{1}=\frac{\alpha_{j}+\alpha_{j 1}}{1-\delta_{0}}, j=1, \cdots, 5$.

\subsection{Data}

Data on real GDP per capita, investment and trade openness were obtained from the Penn World table 7.0. Data on population and FDI come from the World development indicators (WDI) database developed and updated by the World Bank's Development Research Group. All data are annual and available for all variables over the 1960-2007 period. Data on carbone dioxide $\left(\mathrm{CO}_{2}\right)$ emissions are annual and were obtained from WDI database. Data on $\mathrm{SO}_{2}$ emissions were obtained from Stern (2006) [26], Ma and Stern (2006) [27] and updated from the Ace-Asia and Trace-P Modelling and Emission Support System emission database. In terms of country coverage, we have 157 countries to estimate the $\mathrm{CO}_{2}$ emissions equation and 140 countries to estimate the $\mathrm{SO}_{2}$ emissions

\footnotetext{
${ }^{7}$ Small $T$ panel estimation relies mostly on a fixed or a random effects estimator or a combination of a fixed effects estimator and an instrumental variable estimator such as Anderson and Hsiao (1982) or Arellano and Bond's (1991) generalized method of moment's estimator. ${ }^{8}$ In our case, Choi (2001) tests confirm that all variables are $I(1)$ and their first differences are all $I(0)$ which insure that none of the variables is $I(2)$ or beyond.

${ }^{9}$ Weak, strong and super exogeneity are defined in Ericsson (1992). A weakly exogenous variable enters the cointegrating relations, but does not error-correct. A strongly exogenous variable does not error-correct and is not Granger-caused by the other variables in the cointegrating relations. Strong exogeneity is required to remove a variable from the cointegrating relations. Super exogeneity requires weak exogeneity and invariance to jointly hold. It addresses the Lucas critique in policy simulations.

${ }^{10}$ As in Pesaran, Shin and Smith (1999) and Matinez-Zaarzoso and Bengochea-Morancho (2004), variables are assumed to be I(1) and cointegrated for individual countries; similarerror correction representation is also derived.
} 
equation.

Descriptive statistics are presented in Table 1 for the seven aforementioned groups of countries. Countries belonging to the OECD group are the wealthiest. The average per capita income for this group is around \$21,000, followed by MENA, the former USSR and Eastern Europe countries and Central America and the Caribbean which have average per capita income varying around $\$ 7000$. Asia and Africa are the poorest regions with average per capita income of \$4335 and \$1856. OECD countries have the highest per capita domestic investment with an average of \$1629. Central America and the Caribbean, Asia, and the former USSR and Eastern Europe countries come in second with an average level of domestic investment of \$200. MENA, Africa and South America come in last with an average level of domestic investment of less than \$100 \$ per person. OECD countries have also the highest level of per capita foreign investment with an average of \$4767. The MENA group arrives second with an average of $\$ 2075$ followed respectively by Central America and the Caribbean, the former USSR and Eastern Europe, Asia, South America and Africa. The MENA group is also the largest $\mathrm{SO}_{2}$ emitting group with an average of $40 \mathrm{Kg}$ of sulphur dioxide per capita. The OCED group is the largest per capita $\mathrm{CO}_{2}$ emitting group with an average of 8 metric ton. Asia is the largest group in terms of population with an average of 85 million persons over the 48 years covered by our sample. Finally, Africa, and Central America and the Caribbean are the regions exhibiting the largest trade openness with an average of $86 \%$ while the former USSR and Eastern Europe countries make up the least opened region at an average of 53\%.

\section{Results}

The Fisher-type (Choi, 2001) [28] procedure is implemented to test the stochastic properties of the data (Table 2). The empirical results show that all variables are non-stationary in level and stationary in the first difference at 1\% level. We estimated Equation (3) for each pollutant using the Pesaran, Shin and Smith (1999) [23] ARDL fixed effect estimator. Table 3, Table 7, Table 8 and Table 9 present the short run and long run estimated coefficients for $\mathrm{CO}_{2}$ and $\mathrm{SO}_{2}$ emission equations respectively.

\section{1. $\mathrm{CO}_{2}$ Emissions}

Starting with the $\mathrm{CO}_{2}$ equation (Table 3), we notice that the long run estimated coefficients for per capita income and squared per capita income are respectively positive and negative for Africa, Asia and OECD countries, thus lending support for the EKC hypothesis. ${ }^{11}$ Accordingly, increases in per capita income starting from a low level of per capita income tend to increase emissions in Africa, Asia and OECD countries until a critical per capita income level is reached. Beyond this critical level, additional increases in per capita income induce decreases in emissions. The critical level of per capita income in OECD countries is $\$ 23,666$ and it has long been exceeded. Accordingly, future economic growth should induce additional decreases in $\mathrm{CO}_{2}$ emissions in OECD countries. The situation is different in Asia and Africa which have turning points of $\$ 19,725$ and $\$ 8937$ respectively. These critical points are relatively high. The Asian turning point is much higher than China's per capita income and this confirms that Chinese growth has had adverse effects on the environment and that this is likely to continue for perhaps another fifteen years. ${ }^{12}$ The main energy source in Asia is coal and mitigation costs are high (Zhang 2012) [29]. African countries are heavier users of natural gas and petrol. The estimated coefficients on the squared of per capita income are positive and significant for Central American and Caribbean countries and in MENA countries, indicating that emissions grow at an increasing rate with per capita income. In contrast, economic growth has no impact on $\mathrm{CO}_{2}$ emissions in South America, and in the former USSR and Eastern European countries.

\subsubsection{Domestic Investment Impact}

The coefficients on per capita domestic investment in Table 3 are significantly positive at the $1 \%$ level for Asian countries and former USSR and Eastern European countries. It is also positive, but significant only at $10 \%$ for Central American and Caribbean countries and OECD countries. This positive effect means that domestic

\footnotetext{
${ }^{11}$ All the coefficients on per capita GDP and its squared value have the expected signs and those on the long run relationship $\phi_{i}$ are all significant at $5 \%$ level, confirming the existence of an EKC.

${ }^{12}$ Different sources offer different estimates of China's 2012 per capita income. If we assume that it is $\$ 6100$, and that economic growth will be $8 \%$ in the future, the number of years required to reach the critical income level would be: $\ln (19725 / 6100) / \ln (1.08)=15.25$ years. Jalil and Mahmud (2009) using time series data also found evidence of an EKC for China. They too find a turning point in excess of current income levels, but the difference is much smaller and arguably less plausible than ours.
} 
Table 1. Descriptive statistics.

\begin{tabular}{|c|c|c|c|c|c|c|c|}
\hline Region & Variable & Dimension & Obs & Mean & SD & Min & Max \\
\hline \multirow{7}{*}{ Africa } & $\mathrm{CO}_{2} / \mathrm{pop}$ & Metric ton/cap & 1810 & 0.734 & 1.770 & 0.009 & 11.989 \\
\hline & $\mathrm{SO}_{2} / \mathrm{pop}$ & Kg/cap & 1446 & 8.733 & 23.607 & 0.014 & 185.463 \\
\hline & GDP/pop & $1000 \$ /$ сар & 1841 & 1.856 & 2.776 & 0.117 & 26.669 \\
\hline & Investment/pop & $1000 \$ /$ cap & 1841 & 0.441 & 0.894 & -0.193 & 10.037 \\
\hline & FDI/pop & 1000\$/cap & 1318 & 0.034 & 0.158 & -0.445 & 2.909 \\
\hline & Trade openness & $\%$ & 1569 & 86.308 & 62.825 & 4.830 & 453.437 \\
\hline & Population & million & 1872 & 9.650 & 16.065 & 0.041 & 143.312 \\
\hline \multirow{7}{*}{ Asia } & $\mathrm{CO}_{2} / \mathrm{pop}$ & Metric ton/cap & 1177 & 1.456 & 2.536 & 0.004 & 19.103 \\
\hline & $\mathrm{SO}_{2} / \mathrm{pop}$ & Kg/cap & 787 & 4.120 & 6.490 & 0.008 & 52.456 \\
\hline & GDP/pop & $1000 \$ /$ cap & 112 & 4.335 & 6.870 & 0.276 & 50.201 \\
\hline & Investment/pop & 1000\$/cap & 1120 & 1.330 & 2.399 & 0.025 & 17.750 \\
\hline & FDI/pop & $1000 \$ /$ cap & 785 & 0.197 & 0.893 & -0.051 & 9.582 \\
\hline & Trade openness & $\%$ & 1148 & 71.108 & 52.056 & 5.314 & 319.552 \\
\hline & Population & million & 1295 & 85.915 & 235.799 & 0.063 & 1310.584 \\
\hline \multirow{7}{*}{$\begin{array}{c}\text { Central America \& } \\
\text { the Caribbean }\end{array}$} & $\mathrm{CO}_{2} / \mathrm{pop}$ & Metric ton/cap & 939 & 2.864 & 5.155 & 0.038 & 49.315 \\
\hline & $\mathrm{SO}_{2} / \mathrm{pop}$ & Kg/cap & 566 & 21.766 & 51.899 & 0.004 & 438.213 \\
\hline & GDP/pop & $1000 \$ /$ cap & 870 & 7.111 & 5.379 & 1.330 & 29.117 \\
\hline & Investment/pop & 1000\$/cap & 870 & 1.783 & 1.711 & -0.256 & 12.254 \\
\hline & FDI/pop & $1000 \$ /$ cap & 656 & 0.210 & 0.450 & -0.258 & 4.357 \\
\hline & Trade openness & $\%$ & 831 & 86.176 & 42.411 & 18.897 & 217.297 \\
\hline & Population & million & 960 & 5.426 & 16.626 & 0.038 & 108.700 \\
\hline \multirow{7}{*}{$\begin{array}{c}\text { Former USSR \& } \\
\text { Eastern Europe }\end{array}$} & $\mathrm{CO}_{2} / \mathrm{pop}$ & Metric ton/cap & 496 & 6.155 & 3.440 & 0.453 & 16.305 \\
\hline & $\mathrm{SO}_{2} / \mathrm{pop}$ & $\mathrm{Kg} / \mathrm{cap}$ & 541 & 34.950 & 30.131 & 0.065 & 134.864 \\
\hline & GDP/pop & 1000\$/cap & 467 & 7.134 & 4.433 & 1.330 & 23.520 \\
\hline & Investment/pop & $1000 \$ /$ cap & 467 & 1.611 & 1.173 & 0.015 & 7.073 \\
\hline & FDI/pop & 1000\$/cap & 340 & 0.188 & 0.490 & -0.584 & 7.115 \\
\hline & Trade openness & $\%$ & 861 & 53.791 & 31.453 & 4.189 & 145.425 \\
\hline & Population & million & 1008 & 17.094 & 30.436 & 1.210 & 148.490 \\
\hline \multirow{7}{*}{$\begin{array}{l}\text { Middle East \& } \\
\text { North Africa } \\
\text { (MENA) }\end{array}$} & $\mathrm{CO}_{2} / \mathrm{pop}$ & Metric ton/cap & 744 & 5.282 & 9.057 & 0.014 & 75.139 \\
\hline & $\mathrm{SO}_{2} / \mathrm{pop}$ & $\mathrm{Kg} / \mathrm{cap}$ & 701 & 39.513 & 200.572 & 0.017 & 4885.748 \\
\hline & GDP/pop & 1000\$/cap & 652 & 7.012 & 9.023 & 0.334 & 51.625 \\
\hline & Investment/pop & 1000\$/cap & 652 & 2.075 & 2.799 & 0.025 & 22.140 \\
\hline & FDI/pop & $1000 \$ /$ сар & 524 & 0.072 & 0.284 & -1.202 & 3.436 \\
\hline & Trade openness & $\%$ & 732 & 71.055 & 43.505 & 7.040 & 263.877 \\
\hline & Population & million & 816 & 14.789 & 18.224 & 0.078 & 79.935 \\
\hline
\end{tabular}


E. Elmarzougui et al.

\begin{tabular}{|c|c|c|c|c|c|c|c|}
\hline \multicolumn{8}{|l|}{ Continued } \\
\hline \multirow{6}{*}{ South America } & $\mathrm{CO}_{2} / \mathrm{pop}$ & Metric ton/cap & 528 & 1.937 & 1.629 & 0.159 & 7.656 \\
\hline & $\mathrm{SO}_{2} / \mathrm{pop}$ & Kg/cap & 449 & 14.724 & 21.153 & 0.186 & 143.067 \\
\hline & GDP/pop & $1000 \$ /$ cap & 528 & 5.485 & 2.173 & 1.847 & 12.135 \\
\hline & Investment/pop & $1000 \$ /$ cap & 528 & 1.168 & 0.618 & 0.160 & 3.925 \\
\hline & FDI/pop & $1000 \$ /$ cap & 395 & 0.051 & 0.094 & -0.067 & 0.768 \\
\hline & Trade openness & $\%$ & 455 & 70.788 & 32.772 & 19.824 & 172.761 \\
\hline \multirow{6}{*}{ OECD } & $\mathrm{CO}_{2} / \mathrm{pop}$ & Metric ton/cap & 1121 & 8.310 & 4.309 & 0.501 & 22.847 \\
\hline & $\mathrm{SO}_{2} / \mathrm{pop}$ & $\mathrm{Kg} /$ cap & 852 & 27.652 & 24.272 & 0.039 & 151.378 \\
\hline & GDP/pop & $1000 \$ /$ cap & 1142 & 20.929 & 9.061 & 1.781 & 50.960 \\
\hline & Investment/pop & $1000 \$ /$ cap & 1142 & 4.767 & 2.317 & 0.144 & 17.651 \\
\hline & FDI/pop & $1000 \$ /$ cap & 831 & 0.508 & 1.629 & -7.224 & 20.942 \\
\hline & Trade openness & $\%$ & 1064 & 73.789 & 46.258 & 6.320 & 405.113 \\
\hline
\end{tabular}

Table 2. The stochastic properties of the data.

\begin{tabular}{ccccc}
\hline \multirow{2}{*}{ Variables } & \multicolumn{2}{c}{ Variables in level } & \multicolumn{2}{c}{ Variables in first difference } \\
\cline { 2 - 4 } & Statistic $^{13}$ & P-value & Statistic & P-value \\
$\mathrm{CO}_{2}$ /pop & 1.40 & 0.91 & -45.31 & 0.00 \\
$\mathrm{SO}_{2} /$ pop & 3.57 & 0.99 & -31.97 & 0.00 \\
GDP/pop & 12.74 & 1.00 & -38.74 & 0.00 \\
Squared GDP/pop & 14.49 & 1.00 & -32.90 & 0.00 \\
Investment/pop & 5.01 & 1.00 & -42.18 & 0.00 \\
FDI/pop & 9.58 & 1.00 & -31.61 & 0.00 \\
Trade openness & -1.10 & 0.13 & -51.79 & 0.00 \\
\hline
\end{tabular}

Table 3. Long run effects of economic growth, domestic and foreign investment and trade openness on $\mathrm{CO}_{2}$ emissions.

\begin{tabular}{|c|c|c|c|c|c|c|c|}
\hline & Africa & Asia & $\begin{array}{c}\text { Central } \\
\text { America and } \\
\text { the Caribbean }\end{array}$ & $\begin{array}{c}\text { Former USSR } \\
\text { and Eastern } \\
\text { Europe }\end{array}$ & MENA & $\begin{array}{c}\text { South } \\
\text { America }\end{array}$ & OECD \\
\hline \multicolumn{8}{|c|}{ Long run coefficients } \\
\hline GDP/POP & $\begin{array}{c}0.715^{* * *} \\
(4.18)\end{array}$ & $\begin{array}{c}0.789^{* * *} \\
(9.77)\end{array}$ & $\begin{array}{l}0.125 \\
(0.62)\end{array}$ & $\begin{array}{l}0.032 \\
(0.19)\end{array}$ & $\begin{array}{l}0.168 \\
(0.73)\end{array}$ & $\begin{array}{l}-0.165 \\
(-0.60)\end{array}$ & $\begin{array}{c}0.426^{* * *} \\
(2.98)\end{array}$ \\
\hline Squared GDP/POP & $\begin{array}{c}-0.040^{* * *} \\
(-4.40)\end{array}$ & $\begin{array}{c}-0.020^{* * *} \\
(-7.22)\end{array}$ & $\begin{array}{c}0.026^{* * *} \\
(2.78)\end{array}$ & $\begin{array}{l}-0.004 \\
(-0.54)\end{array}$ & $\begin{array}{c}0.022^{* * *} \\
(3.94)\end{array}$ & $\begin{array}{l}0.021 \\
(0.85)\end{array}$ & $\begin{array}{c}-0.009^{* * *} \\
(-3.24)\end{array}$ \\
\hline Investment/pop & $\begin{array}{l}0.345 \\
(1.06)\end{array}$ & $\begin{array}{c}0.280^{* * *} \\
(3.36)\end{array}$ & $\begin{array}{c}0.294^{* *} \\
(1.83)\end{array}$ & $\begin{array}{c}0.367^{* *} \\
(2.66)\end{array}$ & $\begin{array}{l}0.164 \\
(1.11)\end{array}$ & $\begin{array}{l}-0.079 \\
(-0.69)\end{array}$ & $\begin{array}{l}0.272^{*} \\
(1.68)\end{array}$ \\
\hline FDI/pop & $\begin{array}{c}8.407^{* * * *} \\
(5.66)\end{array}$ & $\begin{array}{c}-1.003^{* * *} \\
(-3.62)\end{array}$ & $\begin{array}{l}0.205 \\
(0.50)\end{array}$ & $\begin{array}{c}0.451^{* *} \\
(2.35)\end{array}$ & $\begin{array}{c}3.962^{* * *} \\
(4.82)\end{array}$ & $\begin{array}{c}3.020^{* * * *} \\
(4.05)\end{array}$ & $\begin{array}{l}-0.161 \\
(-1.14)\end{array}$ \\
\hline Trade openness & $\begin{array}{l}0.168 \\
(0.50)\end{array}$ & $\begin{array}{l}0.233 \\
(1.06)\end{array}$ & $\begin{array}{l}-0.039 \\
(-0.07)\end{array}$ & $\begin{array}{l}-0.067 \\
(-0.11)\end{array}$ & $\begin{array}{l}0.959 \\
(0.90)\end{array}$ & $\begin{array}{c}0.541^{* *} \\
(2.06)\end{array}$ & $\begin{array}{c}-1.733^{*} \\
(-1.74)\end{array}$ \\
\hline Constant & $\begin{array}{l}-0.072 \\
(-1.35)\end{array}$ & $\begin{array}{c}-0.153^{* * *} \\
(-2.20)\end{array}$ & $\begin{array}{l}0.091 \\
(0.47)\end{array}$ & $\begin{array}{c}2.034^{* * *} \\
(5.51)\end{array}$ & $\begin{array}{l}0.511^{*} \\
(1.73)\end{array}$ & $\begin{array}{c}0.507^{* * *} \\
(2.54)\end{array}$ & $\begin{array}{c}0.606^{* * *} \\
(3.19)\end{array}$ \\
\hline
\end{tabular}

Values in parentheses are t-statistics. ${ }^{*}, * *$ and $^{* * *}$ denote significance at $10 \%, 5 \%$ and $1 \%$.

${ }^{13}$ This is the inverse normal Z statistics (for more details, see Choi (2001)). 
investment is harmful for the environment in these regions, and more so in Asia. This is not surprising because production technologies in Asia are energy-intensive and highly polluting. Table 4 shows that China and India released an average of 2174 (62\% of the total Asian emissions) and 597 (17\% of the total Asian emissions) million metric tons of $\mathrm{CO}_{2}$ emissions respectively over the period 1960-2007. From Table 4, one can also see that the Russian federation is amongst the highest $\mathrm{CO}_{2}$ emitting countries within its group with an average of 1558 $\mathrm{CO}_{2}$ million metric tons (51\% of its group's total emissions) while Mexico's $\mathrm{CO}_{2}$ emissions make up $83 \%$ of total emissions originating from Central American and Caribbean countries, with an average of $267 \mathrm{CO}_{2}$ million metric tons per year. Finally, the United States is the largest contributor of $\mathrm{CO}_{2}$ emissions among OECD countries with an average of 4681 million metric tons per year.

\subsubsection{Foreign Direct Investment Impact}

The coefficients on per capita foreign direct investment in Table 3 are significantly positive and significant at the 1\% level for Africa, MENA and South America. We find a positive and significant coefficient at the 5\% level for former USSR and Eastern European countries, and a significantly negative coefficient for Asian countries. Unlike domestic investment, foreign investment does not have an adverse effect on the environment everywhere. Foreign direct investment causes more pollution in Africa, MENA and South America, but less in Asia. Thus, multinationals relocating to Asian countries are contributing to reducing per capita $\mathrm{CO}_{2}$ emissions, most likely through the adoption of cleaner technologies. Our results regarding Asian countries are similar to the ones reported in Yang, Brosig and Chen (2013) [12] which were obtained from data about Chinese provinces. The fact that we found that foreign investment is more environmentally friendly than domestic investment generalizes their result for a much larger region. A \$1 increase in per capita FDI in Asia in our study can compensate for the emissions generated by a $\$ 3.58$ increase in domestic investment. By the same token, a $\$ 1$ dollar reduction in FDI in Asia has the same effect as a \$1.27 increase in GDP. From an environmental perspective, this means that decision makers in Asia should encourage and stimulate foreign investment, or at least should not discriminate against it. As shown in Table 5, the highest recipients of FDI in Africa, MENA, South America and the former USSR and Eastern European countries are Nigeria, Lebanon, Brazil and Russian federation respectively with an average of 1.24, 2.46, 9.08 and 9.29 billion dollars respectively. The highest recipient in Asia is always China with an average of 31.82 billion dollars.

Table 6 shows that the hypothesis about domestic and foreign direct investments having similar environmental effects is rejected for most groups of countries. This clearly suggests that domestic and foreign direct investment should not be added up into an investment aggregate. FDI seems to have environmental deleterious effects on the emissions of $\mathrm{CO}_{2}$ in South American, African, MENA and former USSR and Eastern European countries, and beneficial effects on its emissions in Asia, in which the pollution halo hypothesis could not be rejected.

Table 4. Largest $\mathrm{CO}_{2}$ and $\mathrm{SO}_{2}$ average emitting countries by region.

\begin{tabular}{|c|c|c|c|c|}
\hline \multirow{2}{*}{ Region } & \multicolumn{2}{|c|}{$\mathrm{CO}_{2}$ (million metric ton) } & \multicolumn{2}{|c|}{$\mathrm{SO}_{2}(\mathrm{Gg})$} \\
\hline & Value & Country & Value & Country \\
\hline Africa & South Africa & 278.605 & $\begin{array}{l}\text { South Africa } \\
\text { Zambia }\end{array}$ & $\begin{array}{l}1037.93 \\
604.513\end{array}$ \\
\hline Asia & $\begin{array}{l}\text { China } \\
\text { India }\end{array}$ & $\begin{array}{c}2173.074 \\
596.920\end{array}$ & $\begin{array}{l}\text { China } \\
\text { India }\end{array}$ & $\begin{array}{l}6222.247 \\
1551.896\end{array}$ \\
\hline $\begin{array}{l}\text { Central America \& } \\
\text { the Caribbean }\end{array}$ & Mexico & 266.454 & Mexico & 814.352 \\
\hline $\begin{array}{c}\text { Former USSR \& } \\
\text { Eastern Europe }\end{array}$ & $\begin{array}{c}\text { Russian Federation } \\
\text { Ukraine }\end{array}$ & $\begin{array}{c}1558.387 \\
366.181\end{array}$ & $\begin{array}{c}\text { Russian Federation } \\
\text { Poland }\end{array}$ & $\begin{array}{l}4397.063 \\
1467.212\end{array}$ \\
\hline MENA & $\begin{array}{l}\text { Iran, Rep. } \\
\text { Saudi Arabia }\end{array}$ & $\begin{array}{l}206.352 \\
175.412\end{array}$ & $\begin{array}{l}\text { Iran, Rep. } \\
\text { Saudi Arabia }\end{array}$ & $\begin{array}{l}480.463 \\
307.848\end{array}$ \\
\hline OECD & $\begin{array}{l}\text { United States } \\
\text { Japan }\end{array}$ & $\begin{array}{c}4681.355 \\
940.648\end{array}$ & $\begin{array}{c}\text { Germany } \\
\text { United Kingdom }\end{array}$ & $\begin{array}{l}2959.094 \\
2526.917\end{array}$ \\
\hline South America & $\begin{array}{c}\text { Brazil } \\
\text { Argentina }\end{array}$ & $\begin{array}{l}195.662 \\
107.683\end{array}$ & $\begin{array}{l}\text { Chile } \\
\text { Brazil }\end{array}$ & $\begin{array}{l}855.265 \\
749.470\end{array}$ \\
\hline
\end{tabular}


Table 5. Largest average investors and foreign direct investment host countries by region.

\begin{tabular}{ccccc}
\hline \multirow{2}{*}{ Region } & \multicolumn{2}{c}{ FDI (billion \$) } & \multicolumn{2}{c}{ Domestic investment (billion \$) } \\
\cline { 2 - 4 } & Value & Country & Value & Country \\
\hline \multirow{2}{*}{ Africa } & Nigeria & 1.242 & South Africa & Nigeria \\
& South Africa & 0.864 & 6.475 \\
Asia & China & 31.824 & China & 665.898 \\
& Singapore & 6.791 & India & 251.290 \\
Central America \& & Mexico & 7.756 & Mexico & 134.568 \\
the Caribbean & & & 335.955 \\
Former USSR \& & Russian Federation & 9.289 & Russian Federation & 63.437 \\
Eastern Europe & Czech Republic & 4.712 & Poland & 93.157 \\
MENA & Lebanon & 2.461 & Iran, Islamic Rep. & 91.542 \\
& Saudi Arabia & 2.084 & Saudi Arabia & 1359.196 \\
OECD & United Kingdom & 34.406 & United States & 760.363 \\
& United States & 29.080 & Japan & 184.364 \\
South America & Brazil & 9.085 & Brazil & 52.308 \\
\hline
\end{tabular}

Table 6. Testing the equality of domestic and foreign direct investment coefficients.

\begin{tabular}{ccc}
\hline \multirow{2}{*}{ Region } & \multicolumn{2}{c}{ P-value } \\
\cline { 2 - 3 } & $\mathrm{CO}_{2}$ equation & $\mathrm{SO}_{2}$ equation \\
\hline Africa & 0.000 & 0.0472 \\
Asia & 0.000 & 0.1634 \\
Central America \& the Caribbean & 0.247 & 0.4544 \\
Former USSR \& Eastern Europe & 0.029 & 0.437 \\
MENA & 0.000 & 0.001 \\
OECD & 0.000 & 0.040 \\
South America & 0.001 & 0.000 \\
\hline
\end{tabular}

\subsubsection{Trade Openness Impact}

Trade openness does not seem to have a significant effect on $\mathrm{CO}_{2}$ emissions, except for OECD countries and South American countries (Table 3). It reduces the OECD countries' emissions, but it increases the level of emissions emanating from South America. To put things in perspective, $\mathrm{CO}_{2}$ emission reductions permitted by each $1 \%$ increase in trade openness in OECD countries could be offset by an increase of $1.33 \%$ in local investment. Trade openness reducing $\mathrm{CO}_{2}$ emissions in OECD countries was also reported by Managi, Hibiki and Tsurumi (2009) [11]. In contrast, South American countries are harmed by trade openness increases. It could be that increasing openness encourages domestic producers to specialize in more polluting export industries or to use more polluting technologies in import-competing sectors to be more competitive. Increasing openness by $1 \%$ has the same effect as an increase of 3.5\% in per capita FDI. Our results for South America differ from those of Birdsall and Wheeler (1993) [30]. It's true that, the periods covered by the two studies are quite different. Their sample spans the period 1960-1988 and is much shorter than ours (1960-2007). But, Birdsall and Wheeler (1993) [30] results differs about our ones essentially because they did not control for domestic and foreign investments which has biased their trade openness estimate. Regressing our model over the same period of their sample without including domestic and foreign investments yields similar results.

\subsubsection{Short Run Impacts}

The short run adjustment coefficient estimates for the $\mathrm{CO}_{2}$ emission equation are presented in Table 7. Short run coefficients for per capita GDP are significantly positive for African and OECD countries while the ones 
Table 7. Short run adjustment coefficients for $\mathrm{CO}_{2}$ emissions.

\begin{tabular}{|c|c|c|c|c|c|c|c|}
\hline & Africa & Asia & $\begin{array}{c}\text { Central } \\
\text { America and } \\
\text { the Caribbean }\end{array}$ & $\begin{array}{l}\text { Former USSR } \\
\text { and Eastern } \\
\text { Europe }\end{array}$ & MENA & $\begin{array}{l}\text { South } \\
\text { America }\end{array}$ & OECD \\
\hline \multicolumn{8}{|c|}{ Short run coefficients } \\
\hline$\phi_{i}$ & $\begin{array}{c}-0.135^{* * *} \\
(-8.94)\end{array}$ & $\begin{array}{c}-0.370^{* * *} \\
(-12.83)\end{array}$ & $\begin{array}{c}-0.224^{* * *} \\
(-8.95)\end{array}$ & $\begin{array}{c}-0.328^{* * *} \\
(-9.88)\end{array}$ & $\begin{array}{c}-0.273^{* * *} \\
(-8.02)\end{array}$ & $\begin{array}{c}-0.288^{* * *} \\
(-7.94)\end{array}$ & $\begin{array}{c}-0.142^{* * *} \\
(-8.06)\end{array}$ \\
\hline GDP/POP & $\begin{array}{c}0.240^{* * * *} \\
(2.76)\end{array}$ & $\begin{array}{l}-0.010 \\
(-0.09)\end{array}$ & $\begin{array}{l}-0.078 \\
(-0.68)\end{array}$ & $\begin{array}{l}0.246 \\
(1.23)\end{array}$ & $\begin{array}{l}-0.011 \\
(-0.08)\end{array}$ & $\begin{array}{l}-0.099 \\
(-0.44)\end{array}$ & $\begin{array}{c}0.392^{* * *} \\
(2.15)\end{array}$ \\
\hline Squared GDP/POP & $\begin{array}{l}-0.008 \\
(-0.55)\end{array}$ & $\begin{array}{c}0.005^{* *} \\
(1.97)\end{array}$ & $\begin{array}{l}0.011^{* *} \\
(2.14)\end{array}$ & $\begin{array}{l}-0.015 \\
(-1.33)\end{array}$ & $\begin{array}{l}0.001 \\
(0.09)\end{array}$ & $\begin{array}{l}0.021 \\
(1.17)\end{array}$ & $\begin{array}{l}-0.003 \\
(-0.79)\end{array}$ \\
\hline Investment/pop & $\begin{array}{l}-0.022 \\
(-0.45)\end{array}$ & $\begin{array}{c}0.209^{* * *} \\
(5.03)\end{array}$ & $\begin{array}{l}0.074 \\
(1.32)\end{array}$ & $\begin{array}{l}0.228 \\
(2.04)\end{array}$ & $\begin{array}{c}-0.291^{* * *} \\
(-4.96)\end{array}$ & $\begin{array}{l}-0.026 \\
(-0.50)\end{array}$ & $\begin{array}{c}0.159^{* * *} \\
(3.36)\end{array}$ \\
\hline FDI/pop & $\begin{array}{c}-0.483^{* * *} \\
(-3.27)\end{array}$ & $\begin{array}{l}0.143 \\
(1.53)\end{array}$ & $\begin{array}{l}-0.133 \\
(-0.97)\end{array}$ & $\begin{array}{c}-0.157^{* * *} \\
(-1.92)\end{array}$ & $\begin{array}{c}-0.918^{* * *} \\
(-4.57)\end{array}$ & $\begin{array}{l}-0.386 \\
(-1.53)\end{array}$ & $\begin{array}{l}-0.009 \\
(-0.50)\end{array}$ \\
\hline Trade openness & $\begin{array}{l}-0.022 \\
(-0.32)\end{array}$ & $\begin{array}{l}-0.116 \\
(-1.04)\end{array}$ & $\begin{array}{l}-0.295 \\
(-1.53)\end{array}$ & $\begin{array}{l}-0.083 \\
(-0.29)\end{array}$ & $\begin{array}{l}0.105 \\
(0.24)\end{array}$ & $\begin{array}{l}-0.122 \\
(-0.89)\end{array}$ & $\begin{array}{l}0.283 \\
(1.11)\end{array}$ \\
\hline
\end{tabular}

Values in parentheses are t-statistics. ${ }^{* * *}$ and ${ }^{* * *}$ denote significance at $10 \%, 5 \%$ and $1 \%$.

associated to squared per capita GDP are significantly positive for Asian countries and Central American and Caribbean countries, indicating that short run emission levels are a linear monotonic function of growth in Africa and OECD and a quadratic function in the Asia and Central America. Short run domestic investment coefficients are also significantly positive for the Asian, former USSR and Eastern Europe and OECD groups. Domestic investment has a positive impact on the environment in MENA countries, but it does not have any effect on the environment in the other regions.

Unlike in the long run, the short run FDI coefficients are significantly negative for African, MENA and former USSR and Eastern European countries. For these countries, FDI is environmentally-friendly in the short run. The short run domestic investment coefficient is also significantly negative for MENA countries. New investment is cleaner and more efficient than old investments, but as time elapses domestic investment ends up creating more pollution. We found also that the relative speed at which regions adjust/error-correct to shocks were quite similar. African and OECD countries adjust however more slowly.

\section{2. $\mathrm{SO}_{2}$ Emissions}

From Table 8, we can see that the long run effects of economic growth on $\mathrm{SO}_{2}$ emissions vary from being positive for Asia, negative for the OECD and MENA group and insignificant for the other groups of countries. Thus, there is no evidence of a long run EKC in any of the regions, but it is comforting that economic growth brings about long run reductions in $\mathrm{SO}_{2}$ emissions in the MENA and OECD countries. The adverse environmental effect for Asian countries is not surprising, given that increasing energy demand needed to sustain economic growth is satisfied to a large extent by highly polluting energy sources like coal.

\subsubsection{Domestic Investment Impact}

The per capita domestic investment coefficients are significantly positive at 1\% in MENA and South American countries. The qualitative outcome holds, but at the 5\% level, in OECD countries. Per capita investment expansions increase $\mathrm{SO}_{2}$ emissions in the aforementioned regions, but they do not have significant effects for the remaining groups. Table 5 shows that Iran is the largest $\mathrm{SO}_{2}$ emitting country in the MENA group with an average of $480.5 \mathrm{Gg}$ followed by Saudi Arabia ( $308 \mathrm{Gg}$ of $\mathrm{SO}_{2}$ ). Chile is the largest South American $\mathrm{SO}_{2}$ emitting country with an average of $855 \mathrm{Gg}$ followed by Brazil $\left(749 \mathrm{Gg}\right.$ ). And finally Germany is the largest $\mathrm{SO}_{2}$ emitting country amongts OECD countries with an average of $2960 \mathrm{Gg}$ followed by the United Kingdom $(2527 \mathrm{Gg}$ of $\mathrm{SO}_{2}$ ). As for $\mathrm{CO}_{2}$, domestic investment contributes to emissions, but the regions where the long run effect is significant generally differ. 
Table 8. Long run effects of economic growth, domestic and foreign investments and trade openness on $\mathrm{SO}_{2}$ emissions.

\begin{tabular}{ccccccccc}
\hline & Africa & Asia & $\begin{array}{c}\text { Central } \\
\text { America and } \\
\text { the Caribbean }\end{array}$ & $\begin{array}{c}\text { Former USSR } \\
\text { and Eastern } \\
\text { Europe }\end{array}$ & MENA & $\begin{array}{c}\text { South } \\
\text { America }\end{array}$ & OECD \\
& \multicolumn{7}{c}{ Long run coefficients } \\
GDP/POP & 6.274 & $1.251^{*}$ & 2.170 & -7.456 & -6.840 & 3.701 & $-7.767^{* *}$ \\
& $(0.87)$ & $(1.92)$ & $(0.53)$ & $(-1.60)$ & $(-0.65)$ & $(0.66)$ & $(-2.14)$ \\
Squared GDP/POP & -0.469 & -0.022 & -0.078 & 0.295 & $-0.541^{* * *}$ & -0.390 & 0.126 \\
& $(-0.51)$ & $(-1.27)$ & $(-0.42)$ & $(1.15)$ & $(-2.51)$ & $(-0.69)$ & $(1.40)$ \\
Investment/pop & -1.085 & -1.161 & -2.302 & 1.570 & $100.362^{* * *}$ & $7.174^{* * *}$ & $8.821^{* * *}$ \\
& $(-0.20)$ & $(-0.79)$ & $(-0.85)$ & $(0.51)$ & $(8.15)$ & $(3.87)$ & $(2.32)$ \\
FDI/pop & $-99.61^{* *}$ & -3.369 & -16.283 & -7.358 & -254.002 & $42.679^{* * *}$ & -4.257 \\
& $(-2.03)$ & $(-1.25)$ & $(-0.92)$ & $(-0.90)$ & $(-0.69)$ & $(3.08)$ & $(-1.08)$ \\
Trade openness & 0.681 & -0.059 & 7.785 & -18.067 & -2.113 & -0.971 & -15.990 \\
& $(0.10)$ & $(-0.03)$ & $(0.73)$ & $(-1.51)$ & $(-0.03)$ & $(-0.20)$ & $(-0.90)$ \\
Constant & -0.077 & 0.089 & -0.698 & $10.614^{* * *}$ & -50.610 & -0.945 & $4.277^{* * *}$ \\
& $(-0.14)$ & $(0.19)$ & $(-0.35)$ & $(3.14)$ & $(-1.42)$ & $(-0.22)$ & $(2.83)$ \\
\hline
\end{tabular}

Values in parentheses are t-statistics. ${ }^{*},{ }^{* *}$ and ${ }^{* * *}$ denote significance at $10 \%, 5 \%$ and $1 \%$.

\subsubsection{Foreign Investment Impact}

Table 8 shows that foreign direct investment flows have a reducing effect on African $\mathrm{SO}_{2}$ emissions that is significant at 5\% level. On the other hand, FDI significantly increases $\mathrm{SO}_{2}$ emissions of South American countries, but it does not have any effect on the other regions. Thus, multinationals relocating in Africa use cleaner technologies, unlike the multinationals that invest in South America. The fact that domestic investment in South America spurs $\mathrm{SO}_{2}$ emissions may play an important role in enticing firms with looser environmental standards to migrate and establish in the region. These results are quite different compared to the ones for $\mathrm{CO}_{2}$ emissions, for which we had found long run increasing effects for African, former USSR and Eastern European, MENA and South American countries and long run reducing effects for Asia. This justifies conducting separate analyses for different pollutants.

\subsubsection{Trade Openness Impact}

The long run coefficients on trade openness in Table 8 are not significant. This holds for all of the groups. This evidence can be used to refute the hypothesis that trade openness increases $\mathrm{SO}_{2}$ emissions. On the other hand, if trade openness is to have positive environmental effects when it comes to $\mathrm{SO}_{2}$ emissions, these effects will have to be short-lived. These results contrasts with the ones for $\mathrm{CO}_{2}$ emissions for which trade openness contributed to long run decreases in emissions in OECD countries and long run emission increases in South America.

\subsubsection{Short Run Impacts}

The estimated short run coefficients on per capita GDP and its squared value in Table 9 tell us that economic growth induce short-lived increases in $\mathrm{SO}_{2}$ emissions in Africa, South America and in MENA and OECD countries. We find clear evidence of a short run EKC for Asian countries. However, given that the critical revenue beyond which economic growth has a reducing effect on $\mathrm{SO}_{2}$ emissions is very high (over $\$ 30,000$ ), we can say that for most of Asian countries that economic growth contributes to higher $\mathrm{SO}_{2}$ emissions in the short run. Whether there is a short EKC for Central American and Caribbean countries is not as obvious because the t-statistic for the squared of per capita income is very close to being significant at the $5 \%$ level when one tests whether the coefficient is negative or zero. One way or the other, the short run effect of economic growth is that it raises $\mathrm{SO}_{2}$ emissions. The critical level of revenue for the possible EKC is over $\$ 20,000$ and hence above the current per capita income levels observed in this region.

Short run coefficients on domestic investment are positive and significant for MENA, Central American and Caribbean and former USSR and Easter Europe countries. Consequently, domestic investment has adverse short run and long run environmental effects when it comes to $\mathrm{SO}_{2}$ emissions in MENA countries. Fortunately, the 
Table 9. Short run adjustment coefficients for $\mathrm{SO}_{2}$ emissions.

\begin{tabular}{|c|c|c|c|c|c|c|c|}
\hline & Africa & Asia & $\begin{array}{c}\text { Central } \\
\text { America and } \\
\text { the Caribbean }\end{array}$ & $\begin{array}{l}\text { Former USSR } \\
\text { and Eastern } \\
\text { Europe }\end{array}$ & MENA & $\begin{array}{c}\text { South } \\
\text { America }\end{array}$ & OECD \\
\hline \multicolumn{8}{|c|}{ Short run coefficients } \\
\hline$\phi_{i}$ & $\begin{array}{c}-0.063^{* * *} \\
(-7.57)\end{array}$ & $\begin{array}{c}-0.159^{* * *} \\
(-4.54)\end{array}$ & $\begin{array}{c}-0.118^{* * *} \\
(-8.35)\end{array}$ & $\begin{array}{c}-0.185^{* * *} \\
(-5.85)\end{array}$ & $\begin{array}{c}-0.659^{* * *} \\
(-14.41)\end{array}$ & $\begin{array}{c}-0.341^{* * *} \\
(-7.66)\end{array}$ & $\begin{array}{c}-0.056^{* * *} \\
(-4.62)\end{array}$ \\
\hline GDP/POP & $\begin{array}{l}-1.479 \\
(-1.57)\end{array}$ & $\begin{array}{c}1.729^{* * *} \\
(3.35)\end{array}$ & $\begin{array}{c}4.086^{* * *} \\
(3.35)\end{array}$ & $\begin{array}{l}2.865 \\
(1.44)\end{array}$ & $\begin{array}{c}43.044^{* * *} \\
(2.96)\end{array}$ & $\begin{array}{l}-4.545 \\
(-1.12)\end{array}$ & $\begin{array}{l}-1.027 \\
(-0.79)\end{array}$ \\
\hline Squared GDP/POP & $\begin{array}{c}0.306^{* * *} \\
(4.21)\end{array}$ & $\begin{array}{c}-0.027^{* * *} \\
(-2.84)\end{array}$ & $\begin{array}{l}-0.099 \\
(-1.60)\end{array}$ & $\begin{array}{l}-0.145 \\
(-1.10)\end{array}$ & $\begin{array}{l}-0.259 \\
(-0.98)\end{array}$ & $\begin{array}{c}0.6115^{*} \\
(1.78)\end{array}$ & $\begin{array}{l}0.035 \\
(1.02)\end{array}$ \\
\hline Investment/pop & $\begin{array}{l}0.791 \\
(1.47)\end{array}$ & $\begin{array}{l}0.046 \\
(0.10)\end{array}$ & $\begin{array}{c}1.844^{* * *} \\
(3.66)\end{array}$ & $\begin{array}{l}1.847^{* *} \\
(1.98)\end{array}$ & $\begin{array}{c}184.229^{* * *} \\
(15.56)\end{array}$ & $\begin{array}{l}-1.679 \\
(-1.61)\end{array}$ & $\begin{array}{l}0.226 \\
(0.75)\end{array}$ \\
\hline FDI/pop & $\begin{array}{l}4.101 \\
(1.54)\end{array}$ & $\begin{array}{c}1.258^{* * *} \\
(2.90)\end{array}$ & $\begin{array}{l}3.604 \\
(1.45)\end{array}$ & $\begin{array}{l}1.265 \\
(0.70)\end{array}$ & $\begin{array}{c}-288.77 \\
(-1.42)\end{array}$ & $\begin{array}{c}17.959^{* * *} \\
(3.36)\end{array}$ & $\begin{array}{l}0.040 \\
(0.22)\end{array}$ \\
\hline Trade openness & $\begin{array}{l}0.224 \\
(0.37)\end{array}$ & $\begin{array}{l}-0.209 \\
-(0.47)\end{array}$ & $\begin{array}{c}-3.726^{* * *} \\
(-2.25)\end{array}$ & $\begin{array}{l}-1.472 \\
(-0.60)\end{array}$ & $\begin{array}{c}21.613 \\
(0.42)\end{array}$ & $\begin{array}{l}-0.192 \\
(-0.07)\end{array}$ & $\begin{array}{l}1.894 \\
(1.10)\end{array}$ \\
\hline
\end{tabular}

Values in parentheses are t-statistics. ${ }^{* * *}$ and ${ }^{* * *}$ denote significance at $10 \%, 5 \%$ and $1 \%$.

effect of domestic investment on $\mathrm{SO}_{2}$ emissions in Central American and Caribbean countries and in Eastern Europe is short-lived. The reverse is observed for OECD countries: domestic investment has no effect on $\mathrm{SO}_{2}$ emissions in the short run, but it tends to increase $\mathrm{SO}_{2}$ emissions in the long run. The only region for which domestic investment could induce decreases in $\mathrm{SO}_{2}$ emissions in the short run is South America, as the effect is close to being significant at the $5 \%$ level when a one-tailed test is conducted. We found also that the relative speed at which regions adjust/error-correct to shocks were quite similar. African and OECD countries adjust however more slowly.

FDI does not have significant short run effects on $\mathrm{SO}_{2}$ emissions for most regions. However, it contributes to increases in $\mathrm{SO}_{2}$ emissions in the short run for Asian and South American countries. For Asia, we can conclude that FDI matters only in the short run as opposed to South America where FDI has adverse short run and long run environmental effects.

The only group for which trade openness has a temporary significant impact on $\mathrm{SO}_{2}$ emissions is Central America and the Caribbean. For this group, more openness leads to decreases in $\mathrm{SO}_{2}$ emissions, but this effect is short-lived. Trade openness has no effect in the long run for this country. For the other groups of countries, trade openness does not influence $\mathrm{SO}_{2}$ emissions, in the short run as well as in the long run.

\section{Conclusions}

The effects of investment and trade openness on the environment are contentious issues. We use a dynamic panel data estimator to analyze $\mathrm{CO}_{2}$ and $\mathrm{SO}_{2}$ emissions. We decompose investment into domestic and foreign components, in contrast with most other studies that have ignored investment altogether or its domestic component. Our estimator also addresses the endogeneity of income, local investment, Foreign Direct Investment (FDI) and trade openness and allows us to make inference about the long run and short run impacts of growth, investment and trade openness on the environment. Our sample for the analysis of $\mathrm{CO}_{2}$ emissions is made up of 157 countries while our $\mathrm{SO}_{2}$ analysis relies on a sample of 140 emitting countries. Our panels are long, as they cover 48 years (1960-2007). We perform our analyses on seven groups of countries: Africa, Asia, Central America and the Caribbean, former United Socialist Soviet Republic and Eastern Europe countries, the Middle East and North Africa (MENA), South America and OECD countries.

We find that FDI has environmental detrimental effects on the emissions of $\mathrm{CO}_{2}$ in Africa, Middle East and North Africa, South America, and the former United Socialist Soviet Republic and Eastern Europe, but not in Asia where it seems to have beneficial effects. FDI has also prejudicial effects on the emissions of $\mathrm{SO}_{2}$ in $\mathrm{South}$ America and beneficial effects on its emissions in Africa. Domestic investment has either no long run effect or a positive one on $\mathrm{CO}_{2}$ and $\mathrm{SO}_{2}$ emissions, but the regions for which it has a significant long run effect are gener- 
ally not the same for $\mathrm{CO}_{2}$ and $\mathrm{SO}_{2}$ emissions. The only group for which domestic investment has a long run positive effect on both $\mathrm{CO}_{2}$ and $\mathrm{SO}_{2}$ emissions is the OECD. The decomposition of investment into domestic and foreign components is warranted. For Asia's $\mathrm{CO}_{2}$ emissions, FDI has a long run reducing effect while domestic investment has a long run augmenting effect. For former URSS and Eastern Europe countries $\mathrm{CO}_{2}$ emissions, both FDI and domestic investment have long run augmenting effects. For other regions, one type of investment has a significant impact when the other does not. These regional differences in FDI and domestic investment effects possibly reflect weak regulations in lower-income countries.

Trade openness generally does not have a significant long run impact on emissions. The exceptions are $\mathrm{CO}_{2}$ emissions in OECD and South American countries which tend to be respectively reduced and augmented by increases in trade openness. As for the environmental Kuznet Curve hypothesis, long run effects were found for $\mathrm{CO}_{2}$ emissions in Africa, Asia and OECD countries. Short run and long run effects were often different. For example, FDI in former USSR and Eastern European countries tends to reduce (augment) $\mathrm{CO}_{2}$ emissions in the short (long) run. This might explain why there are so many conflicting perceptions regarding the effects of investment, trade openness and economic growth on the environment. While the long run relations tying emissions, investment, trade openness and economic growth together for each region were quite different between $\mathrm{CO}_{2}$ and $\mathrm{SO}_{2}$, we found that the relative speed at which regions adjust/error-correct to shocks was quite similar. African and OECD countries adjust more slowly. In the case of OECD countries, one could conjecture that this outcome is due to the fact that there is too little "policy space" left. OECD countries tend to have low import tariffs, programs in place to attract FDI and stimulate domestic investment and they also have stricter environmental regulations. African countries on the other hand have plenty of "policy space", but are probably constrained by the weakness of their institutions.

\section{References}

[1] Magee, C.S. (2008) New Measures of Trade Creation and Trade Diversion. Journal of International Economics, 75, 349-362. http://dx.doi.org/10.1016/j.jinteco.2008.03.006

[2] Cole, M.A. and Elliott, R.J.R. (2005) FDI and the Capital Intensity of Dirty Sectors: A Missing Piece of the Pollution Haven Puzzle. Review of Development Economics, 9, 530-548. http://dx.doi.org/10.1111/j.1467-9361.2005.00292.x

[3] Levinson, A. and Taylor, M.S. (2008) Unmasking the Pollution Haven Effect. International Economic Review, 49, 223-254. http://dx.doi.org/10.1111/j.1468-2354.2008.00478.x

[4] Grossman, G.M. and Krueger, A.B. (1993) Environmental Impacts of a North American Free Trade Agreement. In: Garber, P.M., Ed., The US-Mexico Free Trade Agreement, MIT Press, Cambridge, 13-56.

[5] Grossman, G.M. and Krueger, A.B. (1995) Economic Growth and the Environment. Quarterly Journal of Economics, 110, 353-377. http://dx.doi.org/10.2307/2118443

[6] Frankel, J.A. and Rose, A.K. (2005) Is Trade Good or Bad for the Environment? Sorting out the Causality. The Review of Economics and Statistics, 87, 85-91. http://dx.doi.org/10.1162/0034653053327577

[7] Hoffmann, R., Lee, C.G., Ramasamy, B. and Yeung, M. (2005) FDI and Pollution: A Granger Causality Test Using Panel Data. Journal of International Development, 17, 311-317. http://dx.doi.org/10.1002/jid.1196

[8] Harbaugh, W.T., Levinson, A. and Wilson, D.M. (2002) Reexamining the Empirical Evidence for an Environmental Kuznets Curve. Review of Economics and Statistics, 84, 541-551. http://dx.doi.org/10.1162/003465302320259538

[9] Lee, C.C., Chiu, Y.B. and Sun, C.H. (2010) The Environmental Kuznets Curve Hypothesis for Water Pollution: Do Regions Matter? Energy Policy, 38, 12-23. http://dx.doi.org/10.1016/j.enpol.2009.05.004

[10] Bernard, J.T., Gavin, M., Khalaf, L. and Voia, M. (2015) The Environmental Kuznet Curve: Tipping Points and Uncertainty. Environmental and Resource Economics, 60, 285-315. http://dx.doi.org/10.1007/s10640-014-9767-y

[11] Managi, S., Hibiki, A. and Tsurumi, T. (2009) Does Trade Openness Improve Environmental Quality? Journal of Environmental Economics and Management, 58, 346-363. http://dx.doi.org/10.1016/j.jeem.2009.04.008

[12] Yang, B., Brosig, S. and Chen, J. (2013) Environmental Impact of Foreign vs. Domestic Capital Investment in China. Journal of Agricultural Economics, 64, 245-271. http://dx.doi.org/10.1111/j.1477-9552.2012.00370.x

[13] Arrow, K., Bolin, B., Costanza, R., Dasgupta, P., Folke, C., Holling, C.S., Jansson, B.O., Levin, S., Maler, K.G. and Perrings, C. (1995) Economic Growth, Carrying Capacity, and the Environment. Science (Washington), 268, 520-520. http://dx.doi.org/10.1126/science.268.5210.520

[14] Tahvonen, O. and Kuuluvainen, J. (1993) Economic Growth, Pollution, and Renewable Resources. Journal of Environmental Economics and Management, 24, 101-118. http://dx.doi.org/10.1006/jeem.1993.1007 
[15] Van Ewijk, C. and Van Wijnbergen, S. (1995) Can Abatement Overcome the Conflict between Environment and Economic Growth? De Economist, 143, 197-216. http://dx.doi.org/10.1007/BF01384535

[16] Stern, D.I., Common, M.S. and Barbier, E.B. (1996) Economic Growth and Environmental Degradation: The Environmental Kuznets Curve and Sustainable Development. World Development, 24, 1151-1160. http://dx.doi.org/10.1016/0305-750X(96)00032-0

[17] Coondoo, D. and Dinda, S. (2002) Causality between Income and Emission: A Country Group-Specific Econometric Analysis. Ecological Economics, 40, 351-367. http://dx.doi.org/10.1016/S0921-8009(01)00280-4

[18] Vogel, D. (1995) Trading up: Consumer and Environmental Regulation in a Global Economy. Harvard University Press, Cambridge.

[19] Braithwaite, J. and Drahos, P. (2000) Global Business Regulation. Cambridge University Press, Cambridge.

[20] Porter, M.E. and Van der Linde, C. (1995) Toward a New Conception of the Environment-Competitiveness Relationship. The Journal of Economic Perspectives, 9, 97-118. http://dx.doi.org/10.1257/jep.9.4.97

[21] Cole, M.A. and Elliott, R.J.R. (2003) Determining the Trade-Environment Composition Effect: The Role of Capital, Labor and Environmental Regulations. Journal of Environmental Economics and Management, 46, 363-383. http://dx.doi.org/10.1016/S0095-0696(03)00021-4

[22] Baltagi, B.H. and Li, Q. (1992) A Note on the Estimation of Simultaneous Equations with Error Components. Econometric Theory, 8, 113-119. http://dx.doi.org/10.1017/S0266466600010768

[23] Pesaran, M.H., Shin, Y. and Smith, R.P. (1999) Pooled Mean Group Estimation of Dynamic Heterogeneous Panels. Journal of the American Statistical Association, 94, 621-634. http://dx.doi.org/10.1080/01621459.1999.10474156

[24] Martinez-Zarzoso, I. and Bengochea-Morancho, A. (2004) Pooled Mean Group Estimation of an Environmental Kuznets Curve for $\mathrm{CO}_{2}$. Economics Letters, 82, 121-126. http://dx.doi.org/10.1016/j.econlet.2003.07.008

[25] Jalil, A. and Mahmud, S. (2009) Environment Kuznets Curve for $\mathrm{CO}_{2}$ Emissions: A Cointegration Analysis for China. Energy Policy, 37, 5167-5172. http://dx.doi.org/10.1016/j.enpol.2009.07.044

[26] Stern, D.I. (2006) Reversal of the Trend in Global Anthropogenic Sulfur Emissions. Global Environmental Change, 16, 207-220. http://dx.doi.org/10.1016/j.gloenvcha.2006.01.001

[27] Ma, C. and Stern, D.I. (2006) Environmental and Ecological Economics: A Citation Analysis. Ecological Economics, 58, 491-506. http://dx.doi.org/10.1016/j.ecolecon.2005.07.023

[28] Choi, I. (2001) Unit Root Tests for Panel Data. Journal of International Money and Finance, 20, $249-272$. http://dx.doi.org/10.1016/S0261-5606(00)00048-6

[29] Zhang, Y. (2012) Seizing the Opportunity of Green Development in China. Development Research Center of the State Council. http://www.worldbank.org/content/dam/Worldbank/document/SR3--229-292.pdf

[30] Birdsall, N. and Wheeler, D. (1993) Trade Policy and Industrial Pollution in Latin America: Where Are the Pollution Havens? The Journal of Environment \& Development, 2, 137-149. http://dx.doi.org/10.1177/107049659300200107 


\section{Appendix}

\section{A. List of Countries Used in $\mathrm{CO}_{2}$ Equation}

Africa. (39 countries): Angola, Benin, Botswana, Burkina Faso, Burundi, Cameroon, Cape Verde, Central African Republic, Chad, Comoros, Congo-Dem. Rep., Congo-Rep., Cote d’Ivoire, Equatorial Guinea, Gabon, Gambia-The, Ghana, Guinea, Guinea-Bissau, Kenya, Liberia, Madagascar, Malawi, Mali, Mauritius, Mozambique, Niger, Nigeria, Rwanda, Senegal, Seychelles, Sierra Leone, South Africa, Swaziland, Tanzania, Togo, Uganda, Zambia, Zimbabwe.

Asia. (26 countries): Bangladesh, Bhutan, Cambodia, China, Fiji, Hong Kong, India, Indonesia, Lao PDR, Macao SAR-China, Malaysia, Maldives, Mongolia, Nepal, Pakistan, Papua New Guinea, Philippines, Samoa, Singapore, Solomon Islands, Sri Lanka, Thailand, Tonga, Vanuatu, Vietnam.

Central America \& the Caribbean. (20 countries): Antigua and Barbuda, Bahamas-The, Barbados, Belize, Costa Rica, Dominica, Dominican Republic, El Salvador, Grenada, Guyana, Haiti, Honduras, Jamaica, Mexico, Nicaragua, Panama, St. Kitts and Nevis, St. Lucia, St. Vincent and the Grenadines, Trinidad and Tobago.

Former United Socialist Soviet Republic and Eastern Europe. (20 countries): Armenia, Azerbaijan, Belarus, Georgia, Moldova, Russian Federation, Ukraine, Uzbekistan, Albania, Bosnia and Herzegovina, Bulgaria, Croatia, Czech Republic, Estonia, Hungary, Latvia, Poland, Romania, Slovak Republic, Slovenia.

Middle East \& North Africa countries (MENA). (17 countries): Algeria, Bahrain, Djibouti, Egypt-Arab Rep., Eritrea, Ethiopia, Iran-Islamic Rep., Jordan, Kuwait, Lebanon, Mauritania, Morocco, Oman, Saudi Arabia, Sudan, Tunisia, Yemen-Rep.

OECD. (24 countries): Australia, Austria, Belgium, Canada, Denmark, Finland, France, Germany, Greece, Iceland, Ireland, Italy, Japan, Netherlands, New Zealand, Norway, Portugal, South Korea, Spain, Sweden, Switzerland, Turkey, United Kingdom, United States.

South America. (11 countries): Argentina, Bolivia, Brazil, Chile, Colombia, Ecuador, Guatemala, Paraguay, Peru, Uruguay, Venezuela-RB.

\section{B. List of Countries Used in $\mathrm{SO}_{2}$ Equation}

Africa. (35 countries): Angola, Benin, Botswana, Burkina Faso, Burundi, Cameroon, Cape Verde, Central African Republic, Chad, Congo, Dem. Rep., Congo-Rep., Cote d’Ivoire, Gabon, Ghana, Guinea, Guinea-Bissau, Kenya, Liberia, Madagascar, Malawi, Mali, Mauritius , Mozambique, Niger, Nigeria, Rwanda, Senegal, Sierra Leone, South Africa, Swaziland, Tanzania, Togo, Uganda, Zambia, Zimbabwe.

Asia. (20 countries): Bangladesh, Bhutan, Cambodia, China, Fiji, Hong Kong, India, Indonesia, Lao PDR, Macao SAR-China, Malaysia, Mongolia, Nepal, Pakistan, Philippines, Singapore, Solomon Islands, Sri Lanka, Thailand, Vietnam.

Central America \& the Caribbean. (14 countries): Antigua and Barbuda, Bahamas-The, Barbados, Costa Rica, Dominican Republic, El Salvador, Guyana, Haiti, Honduras, Jamaica, Mexico, Nicaragua, Panama, Trinidad and Tobago.

Former united socialist soviet republic and Eastern Europe. (20 countries): Armenia, Azerbaijan, Belarus, Georgia, Moldova, Russian Federation, Ukraine, Uzbekistan. Albania, Bosnia and Herzegovina, Bulgaria, Croatia, Czech Republic, Estonia, Hungary, Latvia, Poland, Romania, Slovak Republic, Slovenia

Middle East \& North Africa countries (MENA). (16 countries): Algeria, Djibouti, Egypt-Arab Rep., Eritrea, Ethiopia, Iran-Islamic Rep, Jordan, Kuwait, Lebanon, Mauritania, Morocco, Oman, Saudi Arabia, Sudan, Tunisia, Yemen-Rep.

OECD. (24 countries): Australia, Austria, Belgium, Canada, Denmark, Finland, France, Germany, Greece, Iceland, Ireland, Italy, Japan, Netherlands, New Zealand, Norway, Portugal, South Korea, Spain, Sweden, Switzerland, Turkey, United Kingdom, United States.

South America. (11 countries): Argentina, Bolivia, Brazil, Chile, Colombia, Ecuador, Guatemala, Paraguay, Peru, Uruguay, Venezuela-RB. 